\title{
Thematic Issue Dedicated to the 110th Anniversary of Acad. D. S. Korzhinskii
}

DOI: $10.1134 / \mathrm{S} 0869591110040016$

This issue of the Petrology is dedicated to the 110th anniversary of Dmitrii Sergeevich Korzhinskii, a distinguished Soviet and Russian petrologists, in whose honor the conference "Physicochemical Factors of Petro- and Oregenesis: New Frontiers" was held at the Institute of the Geology of Ore Deposits, Petrography, Mineralogy, and Geochemistry (IGEM), Russian Academy of Sciences, in Moscow on October 7-9, 2009. Presentations made at the conference covered diverse problems of magmatic, metamorphic, and metasomatic petrology, mineralogy, and ore genesis. The papers selected for this issue deal with problems directly or indirectly related to Korzhinskii's extremely broad spectrum of research interests.

The paper by S.P. Korikovsky and L.Ya. Aranovich demonstrates that charnockitization of mafic granulites in the Lapland Belt was associated with the intense infiltration of $\mathrm{Na}-\mathrm{K}-\mathrm{Si}-\mathrm{H}_{2} \mathrm{O}-\mathrm{CO}_{2}-\mathrm{Cl}$ brines into these rocks. These brines alkalinized and gradually debasified the granulites, with charnockite anatexis taking place in the most significantly debasified domains. The removal of $\mathrm{Mg}, \mathrm{Fe}$, and $\mathrm{Ca}$ in the course of pre-charnockite debasification was usually accompanied by the dissemination of these elements, but sometimes they were redeposited and concentrated in the form of basificate veins and melanocratic rims around charnockitoids. All processes-alkaline metasomatism, charnockitization, and the development of basificate veins and rims-occurred at the peak of granulite metamorphism at a temperature close to $800^{\circ} \mathrm{C}$ and a pressure of 9-9.5 kbar.

In the paper by K.K. Podlesskii, consistent thermodynamic data and information on natural mineral assemblages were used to calculate a $P-T$ diagram for aluminous sapphirine-bearing granulites. It was demonstrated that the lower $P-T$ limit of the stability field of the important sapphirine + quartz association is lower than was thought previously: no higher than $835^{\circ} \mathrm{C}$ and $6 \mathrm{kbar}$. This notably modifies the current understanding of critical mineral equilibria in metapelites.

The paper by S.A. Silantyev, L.Ya. Aranovich, and N.S. Bortnikov is devoted to petrological and geochemical aspects of the derivation of oceanic plagiogranites in MAS and is provides evidence that these plagiogranites are derived via their melting from gabbroids at a temperature of $820-850^{\circ} \mathrm{C}$ and pressure of

\section{$2-2.5$ kbar at $a_{\mathrm{H}_{2} \mathrm{O}}=0.9$, under the effect of seawater-} derived fluids.

In their paper, K.A. Savko et al. present data on REE-bearing minerals and their assemblages in the metasedimentary black-shale formation of the Voronezh Crystalline Massif. These authors present pioneering interpretations of prograde metamorphic transformations, reaction structures, isogrades, and mineral equilibria in associations of allanite, thorite, monazite, xenotime, REE-apatite, REE-chlorite, and other REE-bearing minerals at temperatures of $350-550^{\circ} \mathrm{C}$.

The paper by N.S. Gorbachev reports experimental results on fluidized basalts and peridotites as an illustrative example of mantle-crustal interaction, with reference to the Norilsk area. The paper offers a detailed analysis of the derivation of parental mafic magmas from the lithospheric mantle and their further differentiation with the origin of sulfide-silicate melts and the ascent of sulfide melt droplets, together with olivine and chromite protocrysts, thus providing deeper insight into the genesis of high-Ti magnesian mafic magmas.

The paper by O.P. Polyanskii et al. deals with the simulation of the growth of granite-gneiss domes by means of diapirism in Precambrian granite-greenstone belts and suggests a number of sciñnenarios of this process. The authors conclude that the geometry of the diapirs is strongly dependent on the rheology, as also is the maximum possible depths to which the diapirs ascend and which corresponds to the isotherm of $400^{\circ} \mathrm{C}$. The papers sheds light on many important aspects of the process.

The paper by V.L. Vinograd et al. presents a simulated thermodynamic model for the mixing of the solid solution between $\mathrm{K}$-jadeite and diopside, which allowed the authors to tenably simulate complex pyroxene equilibria in deep mantle nodules in kimberlites and lamproites, including clinopyroxene inclusions in diamond, and garnet-clinopyroxene rocks from the ultrahigh-pressure complex of the Kokchetav Massif, Kazakhstan.

All publications offer solutions for a great diversity of current petrological and mineralogical problems at a state of the art level, as was also typical of Korzhinskii's style of thinking and research work. 